Aleksandra M. Mihajlović, PhD

Faculty of Pedagogical Sciences, University of Kragujevac, Jagodina, Serbia

\title{
History of Mathematics and Teaching Mathematics
}

\begin{abstract}
The paper discusses the possibilities of using contents of history of mathematics as a supporting strategy in the teaching of mathematics. There is plenty of research that promotes using historical content in mathematics lessons, but only a few of them are of empirical nature. We will give the brief overview of some studies and consider different possibilities of integrating contents of history of mathematics into the teaching and learning process. Moreover, we will point out some benefits of using the history of mathematics such as: increasing students' motivation, decreasing anxiety related to the subject, building positive attitude towards mathematics, better understanding and development of mathematical concepts, changing the students' perception about mathematics, development of multicultural approach to the subject, more chances for individual work and learning by discovery, helping students to understand the role and importance of mathematics in society etc. Furthermore, we are analyzing the current state of mathematical education in Serbia and some other countries from the aspect of integrating the contents of the history of mathematics into teaching. The main goal of this paper is to investigate the teachers' beliefs and attitudes about possibilities of using history of mathematics in their practice. Based on the results of the inquiry we will suggest possible ways of how to include and use the history of mathematics in mathematics classrooms.
\end{abstract}

Key words: history of mathematics, teaching mathematics, beliefs and attitudes of teachers.

\section{Significance of History of Mathematics}

"Mathematics is one of the oldest of sciences; it is also one of the most active; for its strength is the vigour of perpetual youth."

$$
\text { Andrew Russell Forsyth (1858-1942) }
$$

1 mirko.dejic@gmail.com
Mathematics is a human creation, which has been developing for more than four thousand years. It emerged as a response to different social and economic needs of civilizations such as Babylon, Egyptian, Indian, Chinese, Greek, Roman, to name but a few. In earlier civilizations, the solution to mathematical types of problems lied in empirical research, whereas in later periods deductive theoretical meth- 
ods were applied (Karaduman, 2010). Historical development of mathematics stresses that mathematics as a science has always been connected to economic and social context and development of society. Modern society is more than ever dependent upon technological changes and phases of its development cannot be imagined without mathematics. If we look at the development of other sciences such as physics, chemistry or biology, we may notice that mathematics played an important role in each of them. Thus, we can say that, as understanding of the world is based on scientific theories, mathematics represents an important part of human cultural and scientific heritage.

Some scientists recognize only the cultural side of studying history of mathematics (Gnedenko, 1963). They do not recognize other benefits which we will discuss shortly, and place the history of mathematics in the historical science. In their opinion, new knowledge and ideas do not rely on the past, the past can only prevent progress, and many theories are out of date. This view of the history of mathematics states that a progress comes only with new ideas which did not exist in the past, and that the study of the past is not necessary in the study of mathematics.

If we open a historical book or textbook used in educational settings in Serbia, we shall rarely find anything about a mathematician or historical description of a mathematics discovery. One may generalise that, on the grand scale, in the history of philosophy, only mathematicians of the ancient world and their works are described in any depth. Fortunately, many great mathematicians understood the necessity of studying the history of mathematics (ibidem).

Our belief is that it is necessary for a man to know what provoked the development of mathematical ideas, which methods of study was used in the past and how the problems that were posed were solved. Answers to these issues do not have only cultural and historical significance, but are important for the development of contemporary science. Characteristics of mathematics of a certain epoch, but also of contemporary mathematics, can be understood only in the context of mathematical achievements of the past. One example is how the fifth Euclid's postulate paved the path to the new non-Euclid's geometries, and they in turn formed the foundation for creating more abstract mathematical constructions and axiomatic-deduction systems. A few other examples about the nature of mathematics: in Ancient Greece mathematics was a science about spatial and quantitative relations, but today structures are dominant and the subject of the research is far wider. The term limit and function have been previously connected to mathematical analysis, but today these concepts have exceeded this application. But both measure theory and integration have their deep roots in ancient mathematics. What we are trying to say is that, to know mathematics, one needs to know its history; as Newton expressed metaphorically he had seen further than others by standing upon the shoulders of giants.

It seems therefore that to learn mathematics, it is significant to follow the historical changes in mathematics. Besides knowing historical path of ideas, concepts and facts, which help us to form methodological path, we can create the basis for better understanding of contemporary concepts and views in mathematics, which will modernize methodical directions, which have been frequently outdated.

In the teaching process, special attention should be given to developing positive attitudes of students towards mathematics (Ma\&Kishor, 1997, Akinsola\&Olowojaiye, 2008, Memnun\&Akkaya, 2012). One of the ways to achieve this is to show and convince the students that mathematical knowledge can make their life easier and improve it. But most importantly, a common sense tells us that Mathematics teaching should be organized in the environment in which students will eagerly acquire new knowledge by their own intellectual efforts and abil- 
ities. One of the pedagogical tools for achieving these goals is history of Mathematics, and we will now look at how we use this tool in our work.

\section{Significance and role of History of Mathematics in teaching}

One of the reasons we use history of mathematics in the teaching and learning of the subject is that we believe that if mathematical theories are seen only through their final formulation, without historical interpretations, students can gain a wrong impression about mathematics: they seem to then see it as an artificial creation, which serves mental imagination, but has no connection to practical work or real-life contexts. This can be overcome when students, through historical facts, understand that mathematics from its foundation up to now has played one of the most significant roles in all areas of human life. Students can gain an insight into mathematical concepts in a deeper and more interesting way and from many examples from the past can understand that mathematics is not an isolated discipline (Carter, 2006 according to Goktepe, Ozdemir, 2013).

The idea of using history of mathematics in mathematical education is not new. More than a century ago, Zeuthen (Furinghetti, Radford, 2002) wrote a book on the history of mathematics aimed for teachers. Zeuthen considered history of mathematics to be an integral part of general education of teachers. Almost at the same time, in 1894, Florian Cajori noticed in history of mathematics an inspirational source of information for teachers (Karaduman, 2010). Freudenthal (1981) thought that introducing the history of mathematics into the education of mathematics teachers would provide a background to their mathematical knowledge (Lawrence, 2009). As a starting point towards more serious scientific studies, we can determine the foundation of the working group for History and Pedagogy of Mathematics in 1972 at the Second International
Congress on Mathematical Education (ICME), and the foundation of the International Study Group on Relations between History and Pedagogy of Mathematics in 1976 (Furinghetti, 2005). In the last 20 years the awareness of important role and application of history of mathematics in the process of teaching and learning has been increasing (Goktepe, Ozdemir, 2013). Mathematical Association of America founded The Institute about the History of Mathematics and Its Use in Teaching (IHTM) in 1995. At the meeting of the International Congress on Mathematics Education (ICME) in 1996, the significance of the history of mathematics in motivation of students and using mathematics in teaching activities was stressed. Moreover, at the International Teaching Mathematics Conference (ICTM-2) in 2002 a special panel section was organized with the title The Role of the History of Mathematics in Mathematics Education.

Integrating history of mathematics into the teaching practice helps students understand that mathematics is not fixed and final system of knowledge, but that it represents live developmental process, which is closely linked to other branches of science (Karaduman, 2010). In pedagogical sense, students form a scientific view of the world and become aware of the fact that mathematics always has an important role in the development of entire culture of a certain epoch. Through genesis of a certain concept, students realize that mathematical truths are understood or discovered through usually a very long and hard work. History of mathematics helps students understand that errors, doubts, intuitive reasoning, discussions and alternative approaches are not only legitimate, but an integral part of mathematics in the making (Tzanakis \& Arcavi, 2000, Paschos T. et al., 2004). History of Mathematics represents an inseparable part of mathematics (Goktepe, Ozdemir, 2013).

There are many studies that promote using history in mathematics classes, and they point at the advantages it brings. Wilson \& Chauvot (2000) talk 
about four main benefits of using history of mathematics in the classroom. According to them, its integration into teaching sharpens problem solving skills, makes the basis for better understanding the contents, helps students make different mathematical connections and enlightens the connection between mathematics and society (according to Burns B., 2010). Bidwell (1993) points out that history of mathematics gives mathematics human dimension (according to Kaye E., 2008). Marshall \& Rich (2000) stress that history of mathematics enriches mathematical curriculum and demystifies mathematics, showing that it is the human creation (according to Roscoe, 2010). Jankvist (ibidem) talks about other advantages of using history of mathematics through increased motivation (through creating interest for the subject), and decreased intimidation (through understanding that mathematics is a human creation and that its creators also had to make a great effort in order to come to cognition). According to him, the use of history of mathematics can show students new perspectives on the discipline and enable them to have better insight into specific mathematical contents. On the other hand, the history of Mathematics can serve the teacher as a guide through difficulties, which students face when learning a certain mathematical topic. Those difficulties are often similar to those which were encountered through some historical development of certain concepts.

Gnedenko (Gnedenko, 1996, p. 132) mentions following reasons of why history of mathematics should be studied:

1. History of mathematics gives us a wide perspective of development of mathematics itself, development of its concepts and problems, connection to the praxis, tendencies for generalization and proving scientific assumptions

2. History of mathematics is a part of general history which tells us how mankind was made to develop mathematics and to use its results
3. History of mathematics is one of the prerequisites for further development of contemporary mathematics

4. It is the basis of scientific methodology and one of the most significant sources of the analysis of cognitive processes

5. History of mathematics contributes to improving mathematics teaching

6. History of mathematics is integral part of general human culture.

Many studies, by their results, support the fact that integration of history of mathematics in classes influences students' achievements, their interests and attitudes. Marshall (2000) noticed that using history of mathematics in classes had a positive effect on attitudes of students of secondary schools towards learning mathematics (Goktepe, Ozdemir, 2013). İdikut (2007) made an experimental research with the seventh grade students (ibidem). The main aim of this research was to examine the effect of using history of mathematics as a pedagogical tool on attitudes and achievements of students. The results have shown that there has been no effect on students' attitudes and the level of cognition, but that there was a positive effect on students' achievement in mathematics classes. Karaduman (2010) performed an experimental research in parallel groups with 90 students of primary school (age 10, 11 and 12); students of the experimental group received differentiated instruction and used teaching material with contents from the history of mathematics. Post-test results showed that experimental programme had positive effect on students' achievement, i.e. that students of the experimental group had statistically better results than the students of the control group.

Considering the fact that a teacher is the one who plans, prepares and performs mathematics teaching, his/her role must not be neglected in the teaching process. To which extent and in which ways the history of mathematics will be integrated into teaching depend on attitudes and readiness of 
teachers. Ho (2008) conducted survey among teachers of Singapure schools. According to the results, the author points out three, according to him, significant aspects of using history of mathematics in teaching: potentials, limitations and risks. According to him, most of the teachers do not recognize potentials for using historical approach (contribution to better understanding of the topic, creating a more favourable environment for learning, developing more positive attitudes of both teachers and students). Main limitations, according to teachers, are lack of teacher training in this respect, the lack of time in the curriculum, and the difficulties in assessing the knowledge of students. As to the risks inherent in using history in the teaching of mathematics, most teachers point out they are worried to overstress historical content in comparison to the mathematical, and their possible inability to create mathematical connections in a short time that lesson gives to presentation of such ideas.

In this paper, we wanted to examine the current state of affairs in relation to the use of history of mathematics in primary schools in Serbia, formed by teachers' perceptions.

\section{Research Methodology}

The main research interest of this paper was to examine the current state in lower grades of the primary schools in Serbia concerning the use of the history of mathematics in teaching as well as the attitudes and willingness of teachers to include such content into their work. The aim was realized through the following research tasks:

- To determine to what extent teachers had the opportunity during their schooling to learn some history of mathematics

- To determine to what extent teachers in their current work use the history of mathematics
- To examine what sources teachers use to learn about the history of mathematics, and what sources they use in the classrooms?

- To investigate the readiness of teachers to introduce into their work the history of mathematics

- Researching beliefs of teachers about the role, significance and possibilities of using history of mathematics in teaching.

The general hypothesis of the research is that teachers in elementary mathematics teaching do not use contents of history of mathematics to any great extent.

The survey technique was used in the empirical research, and a questionnaire was created to examine the beliefs and attitudes of teachers about application of the history of mathematics in the teaching of the subject. The questionnaire consisted of two parts. The first part included demographic characteristics of a chosen sample (such as the geographical location of the school in which teachers work, their work experience and level of education). The second part consisted of 9 questions, i.e. 7 questions of the closed type and two five-point Likert scales (the first scale had six and the second one nine items). Data collected by the questionnaire were analysed quantitatively. The statistical analyses included methods of descriptive statistics (frequency, percentage, mean, standard deviation, coefficient of variation) and $\chi^{2}$ test. The independent variables in the data analysis were the level (degree) of education $^{2}$, working experience, and the geographical location of the school.

The research was conducted during the school year 2012/2013 and included the sample of 112 teachers from five areas of the Republic of Serbia

2 Before 1993 primary teachers in Serbia studied at the Teacher Training Colleges (post-secondary schools). In 1993 the Assembly of the Republic of Serbia adopted law on establishing teacher training faculties. According to this classification teachers who graduated from colleges have $6^{\text {th }}$ level of education, and teachers who graduated from faculties have $7^{\text {th }}$ level of education. 
(Jagodina, Rekovac, Kragujevac, Beograd, Vršac). Structure of the sample, according to the degree of education was given in the table 1 .

Table 1. Structure of the sample in relation to the degree of education

\begin{tabular}{|l|c|c|c|}
\hline & $6^{\text {th }}$ level & $7^{\text {th }}$ level & Total \\
\hline Number of teachers & 80 & 32 & 112 \\
\hline Percentage (\%) & 24.1 & 75.9 & 100 \\
\hline
\end{tabular}

Structure of samples in relation to the geographical location of schools in which interviewees work was given in table 2 .

Table 2. Structure of the sample in relation to the geographical location of the school

\begin{tabular}{|l|c|c|c|}
\hline & Urban & Rural & Total \\
\hline Number of teachers & 27 & 85 & 112 \\
\hline Percentage (\%) & 71.4 & 28.6 & 100 \\
\hline
\end{tabular}

Structure of samples in relation to working experience is given in the table 3 .

Table 3. Structure of the sample in relation to the working experience

\begin{tabular}{|l|c|c|c|c|c|}
\hline & \multicolumn{5}{|c|}{ Numbers of years of working experience } \\
\hline & $0-10$ & $11-20$ & $21-30$ & 31 and more & Total \\
\hline Frequency & 26 & 33 & 38 & 15 & 112 \\
\hline $\begin{array}{c}\text { Percentage } \\
(\%)\end{array}$ & 23.2 & 29.5 & 33.9 & 13.4 & 100.0 \\
\hline
\end{tabular}

The data analysis of the research is specially going to be focused on replies in which statistically significant differences were shown, according to independent variables.

\section{Results of the research}

1. The first task of the research was to examine whether teachers during their schooling had the chance to get to know enough of the history of Mathematics so that could meaningfully employ it in their teaching. Only $6.3 \%$ teachers responded to have met with such content in their primary educa- tion, although a greater percentage replied that they had the chance to get to know some of the history of mathematics during their secondary education, $26.8 \%$ to be precise. $69.6 \%$ of the total number of teachers interviewed had experience of the history of mathematics during their university education.

Through this analysis, we could see that there is statistically a significant difference in relation to the education of teachers $\left(\chi^{2}=5,326, d f=1, p=0,021\right)$, and this is shown in the table below:

Table 4. Distribution of replies of teachers in relation to education

\begin{tabular}{|c|c|c|c|c|}
\hline & \multicolumn{2}{|c|}{$\begin{array}{l}\text { I had the opportunity to get } \\
\text { to know contents of history } \\
\text { of Mathematics during uni- } \\
\text { versity or college studies }\end{array}$} \\
\hline & & & no & yes \\
\hline \multirow{4}{*}{$\begin{array}{l}\text { Level } \\
\text { of } \\
\text { educa- } \\
\text { tion }\end{array}$} & \multirow{2}{*}{$\begin{array}{l}6^{\text {th }} \text { level } \\
\text { (under- } \\
\text { graduate) }\end{array}$} & $\mathrm{F}$ & 13 & 14 \\
\hline & & $\%$ & $48.1 \%$ & $51.9 \%$ \\
\hline & \multirow{2}{*}{$\begin{array}{c}7^{\text {th }} \text { level } \\
\text { (postgrad- } \\
\text { uate) }\end{array}$} & $\mathrm{F}$ & 21 & 64 \\
\hline & & $\%$ & $24.7 \%$ & $75.3 \%$ \\
\hline \multirow{2}{*}{\multicolumn{2}{|c|}{ Total }} & $\mathrm{F}$ & 34 & 78 \\
\hline & & $\%$ & $30.4 \%$ & $69.6 \%$ \\
\hline
\end{tabular}

There is a greater percentage of teachers with the $7^{\text {th }}$ level of education in comparison to those with the $6^{\text {th }}$ level, who had opportunity to get to know the contents of history of mathematics during studies. Low value of the phi coefficient $(\Phi=0.218$, $\mathrm{p}=0.021$ ) indicates that there is low association between the level of education of teachers and experience of the history of mathematics during their university education.

2. Almost a fifth of the total number of teachers $19.8 \%$ replied that they used almost always or frequently some content from the history of mathematics. $59.5 \%$ of the total number use them rarely, whereas one fifth, $20.1 \%$ does not use them at all. We compared this with the previous results whether teachers had opportunity to learn about the history of mathematics in their own education. 
Teachers who learnt some history of mathematics during their own studies use it all the time or frequently in their teaching work in higher percentage $(22,1 \%)$, in comparison to those who did not have such experience (14.7\%). However, it has been shown that there is no statistically significant difference $\left(\chi^{2}=4.198, \mathrm{df}=2, \mathrm{p}=0.123\right)$.

We found that there is statistically significant difference when it comes to the geographical location of the school $\left(\chi^{2}=14.590, \mathrm{df}=2, \mathrm{p}=0.001\right)$. There are a greater number of teachers of urban schools who use the history of mathematics in their work (21.5\%), compared to $15.6 \%$ of teachers in rural schools (table 5 ). In addition, only $11.4 \%$ of teachers of urban schools replied that they almost never use history, whereas the percentage of rural schools' teachers were greater $(43.8 \%)$. Cramer's V coefficient $(\mathrm{V}=0.363, \mathrm{p}=0.01)$ suggests a moderate correlation between the geographical location of the school and the use of history mathematics in teaching. Possible reasons might be that rural schools libraries are usually poorly equipped comparing to urban schools' libraries. Furthermore internet is still less available in some rural areas.

Table 5. Distribution of teachers' replies in relation to the geographical location of the school

\begin{tabular}{|c|c|c|c|c|c|}
\hline & \multicolumn{3}{|c|}{$\begin{array}{c}\text { In my work, I use History of } \\
\text { Mathematics contents }\end{array}$} \\
\hline & & & $\begin{array}{l}\text { almost always } \\
\text { and often }\end{array}$ & rarely & $\begin{array}{l}\text { almost } \\
\text { never }\end{array}$ \\
\hline \multirow{4}{*}{$\begin{array}{c}\text { Geographi- } \\
\text { cal location } \\
\text { of the } \\
\text { school }\end{array}$} & \multirow[t]{2}{*}{ Urban } & $\mathrm{F}$ & 17 & 53 & 9 \\
\hline & & $\%$ & $21.5 \%$ & $67.1 \%$ & $11.4 \%$ \\
\hline & \multirow[t]{2}{*}{ Rural } & $\mathrm{F}$ & 5 & 13 & 14 \\
\hline & & $\%$ & $15.6 \%$ & $40.6 \%$ & $43.8 \%$ \\
\hline \multirow{2}{*}{\multicolumn{2}{|c|}{ Total }} & $\mathrm{F}$ & 22 & 66 & 23 \\
\hline & & $\%$ & $19.8 \%$ & $59.5 \%$ & $20.7 \%$ \\
\hline
\end{tabular}

It is interesting to note that the history of mathematics content is used by teachers who have greater working experience (more than 20 years of working experience) $26.9 \%$, whereas this is done by $13.6 \%$ of those who work less than 20 years. Nevertheless, this difference has not been shown to be statistically significant $\left(\chi^{2}=3.106, \mathrm{df}=1, \mathrm{p}=0.078\right)$.
3. We wanted to examine which sources of information teachers use to find appropriate contents from the history of mathematics. Replies of teachers indicate that the greatest percentage of teachers finds such content by using secondary literature $50.9 \%, 37.5 \%$ from the Internet, and $19.6 \%$ from television. It has been shown that there is statistically significant difference $\left(\chi^{2}=7.812, \mathrm{df}=1, \mathrm{p}=0.005\right)$ concerning the level of education of teachers (table 6). $44.7 \%$ of teachers with the level seven use the Internet for finding historical content, whilst only $14.8 \%$ of teachers with level six do this. However, low value of the phi coefficient $(\Phi=0.264, \mathrm{p}=0.005)$ shows that there is low association between the level of education of teachers and using internet for finding contents from the history of mathematics.

Table 6. Distribution of teachers' replies according to the level of education

\begin{tabular}{|c|c|c|c|c|}
\hline \multicolumn{2}{|c|}{} & \multicolumn{2}{c|}{$\begin{array}{c}\text { I find contents from the history } \\
\text { of Mathematics by using the } \\
\text { Internet }\end{array}$} \\
\cline { 3 - 5 } \multicolumn{2}{|c|}{} & \multicolumn{2}{c|}{ no } & yes \\
\hline \multirow{2}{*}{$\begin{array}{c}\text { Level of } \\
\text { education }\end{array}$} & $\begin{array}{c}6^{\text {th }} \\
\text { level }\end{array}$ & F & 23 & 4 \\
\cline { 2 - 5 } & $\begin{array}{c}7^{\text {th }} \\
\text { level }\end{array}$ & F & $85.2 \%$ & $14.8 \%$ \\
\cline { 3 - 5 } & $\%$ & $55.3 \%$ & $44.7 \%$ \\
\hline \multicolumn{2}{|c|}{ Total } & F & 70 & 42 \\
\cline { 3 - 5 } & $\%$ & $62.5 \%$ & $37.5 \%$ \\
\hline
\end{tabular}

4. We asked the teachers what kind of contents and activities from the history of Mathematics they use in their classes. Distribution of replies was shown in table 7.

Table 7. Distribution of teachers' replies to question 4

\begin{tabular}{|l|c|c|}
\hline \multicolumn{1}{|c|}{ In my classes I use: } & $\mathrm{f}$ & $\%$ \\
\hline Stories about famous mathematicians & 41 & 36.6 \\
\hline Anecdotes & 38 & 33.9 \\
\hline $\begin{array}{l}\text { History of development and origin of some } \\
\text { mathematical symbols }\end{array}$ & 35 & 31.3 \\
\hline $\begin{array}{l}\text { History of development and origin of some } \\
\text { mathematical concepts }\end{array}$ & 26 & 23.2 \\
\hline Something else & 6 & 5.4 \\
\hline
\end{tabular}


As in table 7, the greatest percentage of teachers use stories about famous mathematicians and anecdotes from the history of mathematics. Teachers from urban schools use stories from life of the wellknown mathematicians around $42.5 \%$, in comparison to those from the rural schools $21.9 \%\left(\chi^{2}=4,190\right.$, $\mathrm{df}=1, \mathrm{p}=0,041, \mathrm{C}=0,190)$. Distribution of the teachers' replies is seen in table 8 .

Table 8. Distribution of teachers' replies in relation to the geographical location of the school

\begin{tabular}{|c|c|c|c|c|}
\hline \multicolumn{2}{|c|}{} & \multicolumn{2}{c|}{$\begin{array}{c}\text { I use stories about famous } \\
\text { mathematicians in my work }\end{array}$} \\
\cline { 3 - 5 } \multicolumn{2}{|c|}{} & no & yes \\
\hline \multirow{2}{*}{$\begin{array}{c}\text { Geographical } \\
\text { location of } \\
\text { the school }\end{array}$} & urban & rural & 46 & 34 \\
\cline { 3 - 5 } & $\%$ & 57.5 & 42.5 \\
\cline { 3 - 5 } & $\%$ & 78.1 & 7 \\
\hline \multicolumn{2}{|c|}{ Total } & F & 71 & 21.9 \\
\cline { 2 - 5 } & $\%$ & 63.4 & 41 \\
\hline
\end{tabular}

The situation is similar when it comes to using anecdotes $\left(\chi^{2}=4,604, \mathrm{df}=1, \mathrm{p}=0,032, \mathrm{C}=0,199\right)$. $40 \%$ of teachers of urban schools use the anecdotes, and only $18.8 \%$ of teachers of rural schools do this (table 9). Since most teachers use literature as a main source of information, the reason might be that libraries of the rural schools are less equipped than libraries of the urban schools.

Table 9. Distribution of teachers' replies in relation to the surrounding in which the school is situated

\begin{tabular}{|c|c|c|c|c|}
\hline & \multicolumn{2}{|c|}{ I use anecdotes in my work } \\
\hline & & & no & yes \\
\hline \multirow{4}{*}{$\begin{array}{c}\text { Geographical } \\
\text { location of } \\
\text { the school }\end{array}$} & \multirow{2}{*}{ urban } & $\mathrm{F}$ & 48 & 32 \\
\hline & & $\%$ & 60.0 & 40.0 \\
\hline & \multirow{2}{*}{ rural } & $\mathrm{F}$ & 26 & 6 \\
\hline & & $\%$ & 81.3 & 18.8 \\
\hline \multirow{2}{*}{\multicolumn{2}{|c|}{ Total }} & $\mathrm{F}$ & 74 & 38 \\
\hline & & $\%$ & 66.1 & 33.9 \\
\hline
\end{tabular}

It has been shown that there is a greater percentage of teachers with university education $41.2 \%$ who use anecdotes in comparison to teachers with college education $11.1 \%\left(\chi^{2}=8,263, \mathrm{df}=1, \mathrm{p}=0,004\right.$,
$\mathrm{C}=0,262$ ). Comparing these results with the results from the previous questions, we can say that one of the possible reasons can be that teachers, who completed university studies, had learnt more of the history of mathematics than those who graduated at the college.

5. Replying on the question whether the "History of Mathematics contents should be included into the teaching curriculum of Mathematics in primary schools", most of the teachers had positive reply: $48.1 \%$, whereas $32.4 \%$ was not sure and $19.4 \%$ responded negatively. This question was affirmatively answered by a greater percentage of teachers who have been working less than 20 years at schools $(54.4 \%)$ in comparison to those who have been working more than 20 years $(41.5 \%)$. However, this difference has not been shown to be statistically significant $\left(\chi^{2}=5.310, \mathrm{df}=2, \mathrm{p}=0.070\right)$. In addition, there is a higher percentage of teachers with university education (51.9\%) who have affirmative replies in comparison to those with college education (37\%). Nevertheless, testing teachers' replies according to this independent variable, there was no statistically significant difference $\left(\chi^{2}=2.853, \mathrm{df}=2\right.$, $\mathrm{p}=0.240$ ).

6 . When asked whether they were ready to include contents from the history of mathematics into their work to a greater extent, most of the teachers gave positive replies $79.3 \%$ (13.5\% responds that that they are ready to include these contents, and $65.8 \%$ reply that they are ready to include them occasionally). There is no significant difference according to any independent variable: concerning the level of education of teachers $\left(\chi^{2}=1.523, \mathrm{df}=3\right.$, $\mathrm{p}=0.677)$, concerning the geographical location of school $\left(\chi^{2}=6.748, \mathrm{df}=3, \mathrm{p}=0.080\right)$, concerning the working experience $\left(\chi^{2}=1.516, \mathrm{df}=3, \mathrm{p}=0.679\right)$.

7. The main aim of this question was to examine the attitude of teachers about the significance of using contents of history of mathematics in teaching. Table 10 presents each of the item codes used in the first Likert's scale. 
Table 10. Definition of the Likert's scale item codes

\begin{tabular}{|c|l|}
\hline Code & \multicolumn{1}{|c|}{ Items } \\
\hline C1 & $\begin{array}{l}\text { Contents from the history of Mathemat- } \\
\text { ics offer teachers opportunities to motivate } \\
\text { students }\end{array}$ \\
\hline C2 & $\begin{array}{l}\text { Contents from the history of Mathemat- } \\
\text { ics offer teachers opportunities to provoke } \\
\text { curiosity }\end{array}$ \\
\hline C3 & $\begin{array}{l}\text { Contents from the history of Mathemat- } \\
\text { ics offer teachers opportunities towiden } \\
\text { students' knowledge }\end{array}$ \\
\hline C4 & $\begin{array}{l}\text { Contents from the history of Mathematics } \\
\text { offer teachers opportunities to make con- } \\
\text { nections between Mathematics and every- } \\
\text { day life }\end{array}$ \\
\hline C5 & $\begin{array}{l}\text { Contents from the history of Mathemat- } \\
\text { ics offer teachers opportunities to connect } \\
\text { Mathematics and other fields and teaching } \\
\text { subjects }\end{array}$ \\
\hline C6 & $\begin{array}{l}\text { Contents from the history of Mathematics } \\
\text { offer teachers opportunities to make some } \\
\text { mathematical contents closer to students }\end{array}$ \\
\hline
\end{tabular}

Results show that, in general, the attitudes of teachers in regards to the possibilities to use the history of mathematics in mathematics teaching were positive and homogeneous, and this is encouraging. The overall average for the Means of teachers' attitudes toward the possibilities to use history contents was $\mathrm{M}=4.12$ and standard deviation $\mathrm{SD}=0.88$. Coefficient of variation value $\left(C_{V}=21.40\right)$ indicates that teachers' attitude towards possibilities to use history contents in mathematics teaching is relatively the same.

Most of the teachers believe that contents from the history of mathematics help their students to understand better some mathematical contents, enable them to expand their knowledge, provoke their curiosity and give them opportunity to connect mathematical contents with learning and teaching of other subjects and everyday life. In addition, most of the teachers responded that contents from the history of mathematics help them to motivate students (this statement is approved totally or partially by $72.4 \%$ teachers, but there is a number of those who are not sure $8.9 \%$ and who disagree

Table 11. Distribution of teachers' replies to question 7

\begin{tabular}{|c|c|c|c|c|c|c|c|c|c|}
\hline $\begin{array}{l}\text { Item } \\
\text { Codes }\end{array}$ & $\mathrm{N}$ & 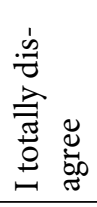 & 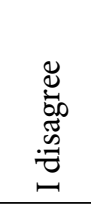 & 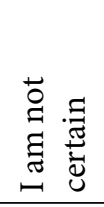 & 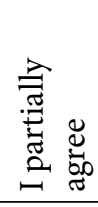 & 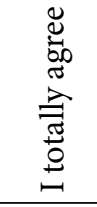 & $\begin{array}{c}\text { Mean } \\
\text { (M) }\end{array}$ & $\begin{array}{c}\text { Standard } \\
\text { Deviation } \\
\text { (SD) }\end{array}$ & $\begin{array}{l}\text { Coefficient of } \\
\text { Variation } \\
\left(\mathrm{C}_{\mathrm{V}}\right)\end{array}$ \\
\hline \multirow{2}{*}{$\mathrm{C} 1$} & \multirow{2}{*}{112} & 2 & 10 & 10 & 49 & 32 & \multirow{2}{*}{3.96} & \multirow{2}{*}{0.99} & \multirow[t]{2}{*}{24.98} \\
\hline & & $1.8 \%$ & $8.9 \%$ & $8.9 \%$ & $43.8 \%$ & $28.6 \%$ & & & \\
\hline \multirow{2}{*}{$\mathrm{C} 2$} & \multirow{2}{*}{112} & 3 & 8 & 2 & 44 & 1 & \multirow{2}{*}{4.22} & \multirow{2}{*}{1.00} & \multirow[t]{2}{*}{23.65} \\
\hline & & $2.7 \%$ & $7.1 \%$ & $1.8 \%$ & $39.3 \%$ & $5.5 \%$ & & & \\
\hline \multirow{2}{*}{ C3 } & \multirow{2}{*}{112} & 0 & 6 & 9 & 54 & 8 & \multirow{2}{*}{4.16} & \multirow{2}{*}{0.80} & \multirow[t]{2}{*}{19.30} \\
\hline & & $0 \%$ & $5.4 \%$ & $8.0 \%$ & $48.2 \%$ & $3.9 \%$ & & & \\
\hline \multirow{2}{*}{$\mathrm{C} 4$} & \multirow{2}{*}{112} & 1 & 7 & 10 & 51 & 6 & \multirow{2}{*}{4.09} & \multirow{2}{*}{0.89} & \multirow[t]{2}{*}{21.76} \\
\hline & & $0.9 \%$ & $6.3 \%$ & $8.9 \%$ & $45.5 \%$ & $2.1 \%$ & & & \\
\hline \multirow{2}{*}{ C5 } & \multirow{2}{*}{112} & 0 & 4 & 12 & 59 & 3 & \multirow{2}{*}{4.12} & \multirow{2}{*}{0.75} & \multirow{2}{*}{18.09} \\
\hline & & $0 \%$ & $3.6 \%$ & $10.7 \%$ & $52.7 \%$ & $9.5 \%$ & & & \\
\hline \multirow{2}{*}{ C6 } & \multirow{2}{*}{112} & 0 & 5 & 15 & 44 & 4 & \multirow{2}{*}{4.18} & \multirow{2}{*}{0.84} & \multirow{2}{*}{20.14} \\
\hline & & $0 \%$ & $4.5 \%$ & $13.4 \%$ & $39.3 \%$ & $9.3 \%$ & & & \\
\hline
\end{tabular}


$10.7 \%)$. It has not been found whether the attitudes about the advantages and importance of using the history of mathematics in teaching were determined by years of working experience, educational degree, and geographical location of the school.

8. One more issue we have dealt with in this research was to investigate causes that affect the use of the contents of history of mathematics in teaching. When creating Likert's scale, we used some items that Siu (2007) used in his research. Siu examined opinion of mathematics teachers about the possible reasons for not using the history of mathematics in the classroom. He created the list of 16 unfavourable factors. We adjusted eight items, from the instrument which was used by Siu, for our scale aimed at primary teachers. ${ }^{3}$ Table 12 presents each of the item codes used in the Likert's scale.

Table 12. Definition of the Likert's scale item codes

\begin{tabular}{|c|c|}
\hline Code & Items \\
\hline HM1 & $\begin{array}{l}\text { I do not use contents from history of Math- } \\
\text { ematics in my classes, because there is not } \\
\text { enough literature about their application in } \\
\text { classes }\end{array}$ \\
\hline HM2 & $\begin{array}{l}\text { I do not have enough time to use contents } \\
\text { from history of Mathematics because of the } \\
\text { compulsory curriculum }\end{array}$ \\
\hline HM3 & $\begin{array}{l}\text { Students do not have enough general knowl- } \\
\text { edge, so that they can understand and appreci- } \\
\text { ate contents from the history of Mathematic }\end{array}$ \\
\hline HM4 & $\begin{array}{l}\text { Using contents from the history of Mathemat- } \\
\text { ics does not influence better students' achieve- } \\
\text { ment }\end{array}$ \\
\hline HM5 & $\begin{array}{l}\text { I am not sufficiently trained for using contents } \\
\text { of the history of Mathematics in teaching }\end{array}$ \\
\hline HM6 & $\begin{array}{l}\text { Students do not like contents from the history } \\
\text { of Mathematics }\end{array}$ \\
\hline HM7 & $\begin{array}{l}\text { Contents from the history of Mathematics are } \\
\text { boring for students }\end{array}$ \\
\hline HM8 & $\begin{array}{l}\text { Using contents from the history of Mathemat- } \\
\text { ics can only confuse students }\end{array}$ \\
\hline HM9 & $\begin{array}{l}\text { Contents from the history of Mathematics do } \\
\text { not have connection to Mathematics }\end{array}$ \\
\hline
\end{tabular}

3 Items 1, 2, 3, 4, 5, 6, 7 and 9 (table 11) are modified items from the questionnaire used by Siu (2007).
Values of the calculated statistical parameters (mean, standard deviation, coefficient of variation) show that teachers believe that the greatest obstacle for using history of mathematics in teaching are the insufficient use of appropriate literature and lack of time (table 13). Nevertheless, values of the coefficient of variation show that attitudes of teachers on these issues are heterogeneous; $54.5 \%$ of teachers think they haven't got enough time for historical research, but more than half of the teachers, 50.9\%, agree with the statement that there is not enough literature, whilst the second half of our population is not sure or disagrees. Siu (2007) got similar results: $53 \%$ of mathematics teachers see the problem in insufficient time in the classes, and 50\% think that the problem is the lack of literature and adequate teaching materials. It is interesting that $46.5 \%$ of teachers disagree (totally or partially) with the statement that they are not sufficiently trained for using the history of mathematics in teaching, $19.6 \%$ are not sure, and $26.8 \%$ agree with this statement. (Siu in his research came to the result that $78 \%$ of mathematics teachers think that they lack adequate training for using historical content). In relation to this issue then, the attitudes of teachers are heterogeneous.

It is encouraging to find that, for example, the primary teachers in our survey negatively marked the statement that the history of Mathematics does not have any connection to mathematics. Yet, despite the fact that $70.6 \%$ of teachers totally or partially disagree with this statement, there is a smaller percentage of those who are not sure (14.3\%), and those who think that the history of mathematics has nothing to do with mathematics make the rest: $6.3 \%$. When it comes to the teachers of mathematics, Sui (2007) finds that this statement is not approved by $87.49 \%$. Primary teachers are divided in their opinion about the statement that using contents from the history of mathematics does not influence pupils' achievement for the better. The greatest percentage is given to those who say they are not certain in this respect: $27.7 \%$. Siu came to the similar results. 
Table 13. Distribution of teachers' replies to question 8

\begin{tabular}{|c|c|c|c|c|c|c|c|c|c|c|c|}
\hline $\begin{array}{l}\text { Item } \\
\text { code }\end{array}$ & $\mathrm{N}$ & & 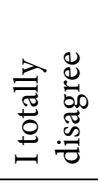 & 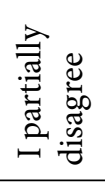 & 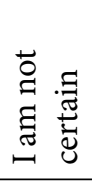 & 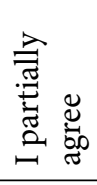 & 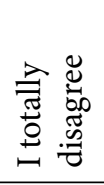 & 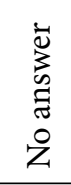 & $\begin{array}{c}\text { Mean } \\
(\mathrm{M})\end{array}$ & $\begin{array}{c}\text { Standard } \\
\text { Deviation } \\
\text { (SD) }\end{array}$ & $\begin{array}{c}\text { Coefficient of } \\
\text { Variation } \\
\left(\mathrm{C}_{\mathrm{V}}\right)\end{array}$ \\
\hline \multirow{2}{*}{ HM1 } & \multirow{2}{*}{103} & $\mathrm{f}$ & 9 & 17 & 20 & 38 & 19 & 9 & \multirow{2}{*}{3.40} & \multirow{2}{*}{1.22} & \multirow[t]{2}{*}{35.77} \\
\hline & & $\%$ & 8.0 & 15.2 & 17.9 & 33.9 & 17.0 & 8 & & & \\
\hline \multirow{2}{*}{ HM2 } & \multirow{2}{*}{104} & $\mathrm{f}$ & 19 & 12 & 12 & 44 & 17 & 8 & \multirow{2}{*}{3.27} & \multirow{2}{*}{1.37} & \multirow[t]{2}{*}{41.81} \\
\hline & & $\%$ & 17.0 & 10.7 & 10.7 & 39.3 & 15.2 & 7.1 & & & \\
\hline \multirow{2}{*}{ HM3 } & \multirow{2}{*}{104} & $\mathrm{f}$ & 21 & 26 & 16 & 31 & 10 & 8 & \multirow{2}{*}{2.84} & \multirow{2}{*}{1.32} & \multirow[t]{2}{*}{46.37} \\
\hline & & $\%$ & 18.8 & 23.2 & 14.3 & 27.7 & 8.9 & 7.1 & & & \\
\hline \multirow{2}{*}{ HM4 } & \multirow{2}{*}{105} & $\mathrm{f}$ & 22 & 20 & 31 & 22 & 10 & 7 & \multirow{2}{*}{2.79} & \multirow{2}{*}{1.26} & \multirow[t]{2}{*}{45.19} \\
\hline & & $\%$ & 19.6 & 17.9 & 27.7 & 19.6 & 8.9 & 6.3 & & & \\
\hline \multirow{2}{*}{ HM5 } & \multirow{2}{*}{104} & $\mathrm{f}$ & 33 & 19 & 22 & 28 & 2 & 8 & \multirow{2}{*}{2.49} & \multirow{2}{*}{1.25} & \multirow[t]{2}{*}{50.05} \\
\hline & & $\%$ & 29.5 & 17.0 & 19.6 & 25.0 & 1.8 & 7.1 & & & \\
\hline \multirow{2}{*}{ HM6 } & \multirow{2}{*}{100} & $\mathrm{f}$ & 40 & 20 & 24 & 13 & 3 & 12 & \multirow{2}{*}{2.19} & \multirow{2}{*}{1.19} & \multirow[t]{2}{*}{54.18} \\
\hline & & $\%$ & 35.7 & 17.9 & 21.4 & 11.6 & 2.7 & 10.7 & & & \\
\hline \multirow{2}{*}{ HM7 } & \multirow{2}{*}{104} & $\mathrm{f}$ & 49 & 19 & 20 & 12 & 4 & 8 & \multirow{2}{*}{2.07} & \multirow{2}{*}{1.22} & 58.86 \\
\hline & & $\%$ & 43.8 & 17.0 & 17.9 & 10.7 & 3.6 & 7.1 & & & \\
\hline HMS & $10 ?$ & $\mathrm{f}$ & 48 & 17 & 21 & 16 & 0 & 10 & 205 & 115 & 55.95 \\
\hline 1117vo & 102 & $\%$ & 42.9 & 15.2 & 18.8 & 14.3 & 0 & 8.9 & 2.00 & $1.1 \mathrm{~J}$ & \\
\hline HMO & 102 & $\mathrm{f}$ & 61 & 18 & 16 & 7 & 0 & 10 & 170 & 097 & 5736 \\
\hline IIIVIS & 102 & $\%$ & 54.5 & 16.1 & 14.3 & 6.3 & 0 & 8.9 & 1.70 & 0.01 & \\
\hline
\end{tabular}

The statement that contents from the history of mathematics can only confuse pupils in the classrooms is completely and partially disapproved by $58.1 \%$ of teachers. Similarly, most of the teachers totally or partially disagree that contents of the history of mathematics is boring for their pupils (60.8\%), that pupils do not like it (53.6\%), or that pupils themselves do not have enough general knowledge in order to understand and appreciate such content (42\%). Considering the values of the coefficient of variation, we can conclude that attitudes of teachers are heterogeneous for these questions. Siu finds that $36 \%$ of mathematics teachers believe that students do not have enough general knowledge to appreciate historical contents.
Replies of teachers to these questions were compared to the replies on the question to which extent they use the content from the history of Mathematics in their work. The greatest percentage of teachers $57.8 \%$ who almost never or rarely use such content replied that this was because they did not have enough time in their lessons due to the need to cover the compulsory programme. $52.4 \%$ replied that they did not have access to relevant literature.

9. Considering the fact that one of the forms of compulsory professional development of teachers is attending accredited seminars, we wanted to examine whether the teachers would like some of the topics at this seminar to be devoted to possibilities of applying history of mathematics in primary 
teaching. The greatest percentage of the total number of teachers replied affirmatively, $68.8 \%$. Some teachers were not sure, $12.5 \%$ and $18.8 \%$ of them responded negatively. We compared answers to these questions to replies to the previous question.

Most of the teachers (58.3\%) who said they wanted to hear more about the history of mathematics in seminars replied that the reason they do not use more of history in their lessons was the lack of literature and lack of time during regular classes. About one half of these teachers, 56.2\% think that they are trained, and $15.1 \%$ are not sure, whereas $28.8 \%$ think that they are not sufficiently trained to include such content in their work.

\section{Concluding remarks}

It is very important for future primary school teachers and mathematics teachers to get to know the genesis of mathematical concepts and statements and many studies and research point at this (Schubring et all., 2000, Dejić, Egerić, 2010, Goktepe, Ozdemir, 2013). In teaching and learning of mathematics, students often form certain mathematical concepts in the way these concepts have been themselves formed: direct counting, measuring, observation, etc. of the real objects. Of course, the students do not go through the complete historical development (which sometimes lasts for centuries) in learning the certain mathematical concepts, but use shorter routes which can be facilitated by appropriate methodological transformation of the mathematical contents (Dejić, Egerić, 2010).

In mathematics teaching in the lower grades of the primary school and later, teachers can use facts from the history of mathematics to get students interested in the topic they teach. Telling appropriate anecdotes about great mathematicians, contributes to pedagogical work by example in the best possible way. There is a general agreement that famous historical anecdotes are effective in order to break monotony and make the class more interesting (Ho,
2008). If children like a mathematician, they may get interested in his/her work more. Gauss was only 9 when he managed to add numbers from 1 to 100 in a very short time. For primary pupils it can be very interesting to understand in which way he did this. Thales managed to measure the height of Cheops pyramid by using its shadow, and was known as one of the seven wise man of Greece, both of these facts can be easily used in the classroom to engage children. Various measuring in nature can lead children to forming the concept of length, area or volume, in the same way the ancient Egyptians did this living on the Nile River. For example, similarly to the ancient Egyptians, students can get the right angle with the aid of a rope with knots. Bidwell (1993) stresses that history of mathematics can be used in teaching in three ways: anecdotal display, injecting anecdotal material as the course is presented, and teaching topics in the way they have been developed through the history (Haverhals, Roscoe, 2010).

Results of our research show that whilst teachers have a positive attitude towards the history of mathematics they don't integrate it into teaching much. The most common reasons are lack of appropriate literature and methodological guidelines, and lack of time due to the delivery of the compulsory curriculum. Unfortunately, despite the positive attitude of majority of teachers who took part in this research, a certain number of them were reluctant to use historical contents in their teaching, or were not sure of the effects of such approach (some believed that they would bore their pupils, others that that pupils would not like such approach, and some that the use of history of mathematics in mathematics teaching does not influence achievements of pupils). It was encouraging, for us, to find that during their studies at the teacher training institutions, teachers reported having met with some content from the history of mathematics.

On the other hand, the history of mathematics cannot be found in our curriculum, and 
it is not mentioned in many textbooks. ${ }^{4}$ Results of our research show that there is at least an interest of teachers to participate in accredited seminars which would cover the topics about the inclusion of the history of mathematics in teaching. Unfortunately, such programmes do not currently exist. Mathematical society Archimedes has been organising different seminars for teachers of mathematics and sometimes they present topics relating to the history of mathematics. Also, Serbian mathematical congresses, held every fourth year, have a section for the topics on teaching and the history of mathematics. So although not enough attention has so far been paid to the connection between the history of mathematics and mathematics teaching in our country, we believe that this can be improved. One of the ways is to organise seminars by professional associations in which teachers would be educated how to use history of mathematics in their teaching. Journals for students and teachers could contain topics from the his- tory of mathematics that would follow mathematics curriculum. When writing mathematical textbooks, special attention could be paid to appropriate contents from the history of mathematics, which would expand students' knowledge in social and cultural context. Trifunović (1980) suggests writing separate textbooks from the history of mathematics as it is the case in some other countries (Russia, France, Italy, Romania).

It should be stressed that when we talk about the application of the elements of the history of mathematics in mathematics education, we do not talk about historicism. Too much historical material, which would be learnt for the sake of learning, would burden mathematical teaching. A teacher must be trained for methodological adjustment and application of the suitable contents. All of this implies that special attention should be given to the education of teachers, because the teacher is, and remains the major factor of students' achievements in the educational process.

\section{References}

- Akinsola, M. K., Olowojaiye, F. B. (2008). Teacher instructional methods and students attitudes towards mathematics. International Electronic Journal of Mathematics Education, 3(4), 60-73. Retrieved August 17, 2014. from http://www.iejme.com/012008/d4.pdf

- Bertolino, M. (1979). Uloga matematike u obrazovanju celovite ličnosti [Role of mathematics in education]. In: Bertolino M. et all. (ed.). Neki problemi savremenog matematičkog obrazovanja (9-33). Beograd: Institute for Educational Research.

- Burns, B. A. (2010). Pre-Service Teachers' Exposure to Using the History of Mathematics to Enhance Their Teaching of High School Mathematics. Issues in the Undergraduate Mathematics Preparation of School Teachers: The Journal, 4, 1-9.

- Carter, D. B. (2006). The Role of the History of Mathematics in Middle School. Unpublished master's thesis, East Tennessee State University, United States. Retreived August $10^{\text {th }}, 2014$. from http://www.cimm.ucr.ac.cr/ ciaem/articulos/historia/textos/Therole\%20of\%20the\%20history\%20of\%20mathematics\%20in\%20the\%20 middle\%20school. ${ }^{\star}$ Donette\%20Barker,\%20Carter. ${ }^{\star}$ historia-\%20tesis\%20completa.pdf

\footnotetext{
4 The exception is mathematics textbook for the 4 th grade, published by Kreativni centar (Dejić, M., Milinković, J., Djokić, O., 2012). In this textbook authors presented some historical content about mathematical concepts in a popular way.
} 
- Dejić, M. (2013). Broj, mera i bezmerje [Number, measure, infinity]. Beograd: Učiteljski fakultet.

- Dejić, M., Egerić, M. (2010). Metodika nastave matematike [Methodology of Teaching Mathematics]. Jagodina: Učiteljski fakultet u Jagodini.

- Dejić, M., Milinković, J., Djokić, O. (2012). Matematika, udžbenik za četvrti razred osnovne škole [Mathematics textbook, 4th grade]. Beograd: Kreativni Centar.

- Furinghetti, F. (2005). History and mathematics education: a look around the world with particular reference to Italy. Mediterranean Journal for Research in Mathematics Education 3 (1-2), 1-20.

- Furinghetti, F., Radford, L., (2002). Historical conceptual developments and the teaching of mathematics: from phylogenesis and ontogenesis theory to classroom practice. In: D. L. English (ed.). Handbook of International Research in Mathematics Education (631-654). Mahwah, NJ: Lawrence Erlbaum.

- Gnedenko, B.,V. (1996). Uvod u struku matematika (prevod), Kragujevac: DSP mecatronic.

- Goktepe, S., Ozdemir, A. S. (2013). An example of using history of mathematics in classes. European Journal of Science and Mathematics Education, 1 (3), 125 -136.

- Haverhals, N., Roscoe, M. (2010). The history of mathematics as a pedagogical tool: Teaching the integral of the secant via Mercator's projection. The Montana Mathematics Enthusiast, 7 (2\&3), 339-368.

- Ho, W. K. (2008). Using history of mathematics in teaching and learning of mathematics in Singapore. Paper presented at Raffles International Conference on Education, Singapore. Retrieved on July $10^{\text {th }}, 2014$. from http://math.nie.edu.sg/wkho/Research/My\%20publications/Math\%20Education/hom.pdf

- Klowss, J. (2009). Using History to Teach Mathematics. In: Paditz L. \& Rogerson A. (ed.). Proceedings of the $10^{\text {th }}$ International Conference Models in Developing Mathematics Education (328-330). Dresden: The University of Applied Sciences.

- Karaduman, G. B. (2010). A sample study for classroom teachers addressing the importance of utilizing history of math in math education. Procedia Social and Behavioral Sciences, Elsevier, 2, 2689-2693.

- Kaye, E. (2008). The aims of and responses to a history of mathematics videoconferencing project for schools. In: Joubert, M. (ed.). Proceedings of the British Society for Research into Learning Mathematics, 28 (3), 66-71. London: British Society for Research into Learning Mathematics.

- Lawrence, S. (2009). What works in the Classroom Project on the History of Mathematics and the Collaborative Teaching Practice. Paper presented at CERME 6, Lyon France. Retrieved on September 12 ${ }^{\text {th }}$ 2014, from http://ife.ens-lyon.fr/publications/edition-electronique/cerme6/wg15-08-lawrence.pdf

- Ma, X., \& Kishor, N. (1997). Assessing the relationship between attitude toward mathematics and achievement in mathematics: A meta-analysis. Journal for Research in Mathematics Education, 28, 26-47.

- Man-Keung, C. (2000). The ABCD of using history of mathematics in the (undergraduate) classroom. In: Katz V. J. (ed.). Using History to Teach Mathematics: An International Perspective (3-10). The Mathematical Association of America.

- Memnun, D. S., Akkaya R. (2012). Pre-service teachers'attitudes toward mathematics in Turkey. International Journal of Humanities and Social Science, 2 (9), 90 - 99.

- Paschos, T., Farmaki, V., Klaudatos, N. (2004). Integrating the History of Mathematics in Educational Praxis. An Euclidean Geometry Approach to the Solution of Motion Problems. In: Høines M., Fuglestad A. (ed.). 
Proceedings of the $28^{\text {th }}$ annual conference of the International Group for the Psychology of Mathematics Education (Vol. 3, 505-512). Bergen, Norway: Bergen University College.

- Radford, L., Furinghetti, F., Katz, V. (2007). Introduction The topos of meaning or the encounter between past and present. Educational Studies in Mathematics, 66 (2), 107-110.

- Kolpas, S. J. (2002). Let your fingers do the multiplying. Mathematics Teacher, 95 (4), 246-251.

- Siu, M. K. (2007). No, I don't use history of mathematics in my class. Why? In F. Furinghetti et all (ed.). Proceedings HPM2004 \& ESU4 (268-277). Uppsala: Uppsala Universitet.

- Schubring G. et all (2000). History of mathematics for trainee teachers. In: Fauvel J., Maanen J. V. (ed.). History in Mathematics Education, The ICMI Study (201-240). Dordrecht: Kluwer Academic Publishers.

- Trifunović, D. (1980). Neke napomene o istoriji matematike u nastavi. [Some notes on the history of mathematics in teaching]. Zbornik Instituta za pedagoška istraživanja 13. Beograd: Institut za pedagoška istraživanja, Prosveta, 47-52.

- Tzanakis, C., Arcavi A. (2000). Integrating history of mathematics in the classroom: an analytic survey. In: Fauvel J., Maanen J. V. (ed.). History in Mathematics Education, The ICMI Study (201-240). Dordrecht: Kluwer Academic Publishers. 


\author{
др Мирко Дејић \\ Учитељски факултет, Универзитет у Београду \\ др Александра Михајловић \\ Факултет педагошких наука, Универзитет у Крагујевцу
}

\title{
Историја математике и настава математике
}

У овом раду бавићемо се могућностима примене садржаја историје математике као подршке настави математике. Постоји велики број истраживања која промовишу коришћење историјских садржаја на часовима математике, али је мали број њих емпиријског карактера. У раду ћемо дати кратак приказ неких истраживања, указаћемо на различите могућности укључивања садржаја историје математике у наставу и истакнућемо неке предности њиховог коришћења, попут: повећања мотивације ученика, смањивања страха од предмета, хуманизације математике, изградње позитивног става према математици, бољег разумевања математике и развоја математичких појмова, промене перцепције ученика о математици, развијања мултикултуралног приступа, пружања ученицима могућности да самостално истражују, бољег схватања улоге и важности математике у друштву итд. Такође, анализираћемо ситуацију у математичком образовању у неким другим земљама и у Србији са аспекта интеграције садржаја историје математике у наставу. Главно истраживачко интересовање нашег рада односило се на утврђивање постојећег стања у нижим разредима основне школе по питању коришћења садржаја историје математике у настави, као и ставова и спремности учитеља да у већој мери у свој наставни рад укључе ове садржаје. Основни циљ рада било је испитивање мишљења и ставова учитеља о могућностима коришћења садржаја историје математике у наставном раду. Општа хипотеза спроведеног истраживања је да учитељи у почетној настави математике не користе у довољној мери садржаје историје математике. Истраживање је спроведено школске 2012/2013. године и обухватило је узорак од сто дванаест учитеља из пет општина Републике Србије. За прикупљање података коришћена је техника анкетирања. Резултати истраживања показали су да, без обзира на чињеницу да већина учитеља има позитиван став према коришћењу историје математике у настави, ипак, то у знатно мањем проценту примењују у пракси. Најчешћи разлози су недостатак одговарајућих књига и методичких упутстава, као и недовољно времена због реализације обавезног програма. Показало се да постоји интересовање учитеља да се на акредитованим семинарима више пажње посвети примени историје математике у настави. Требало би садржаје историје математике укључити и у часописе за ученике, али и за наставнике, а нарочиту пажњу треба обратити при писању математичких уџбеника.

Клучне речи: историја математике, настава математике, мишљење и ставови учитеља. 